\title{
Implementasi Program Pagu Wilayah Kecamatan Bidang Ekonomi untuk Peningkatan Kapasitas Sosial dan Ekonomi Masyarakat di Kabupaten Temanggung
}

\author{
Yuni Astuti ${ }^{1}$, Agnes Sunartiningsih ${ }^{2}$
}

\begin{abstract}
Abstrak
Pemerintah Kabupaten Temanggung melaksanakan Program Pagu Wilayah Kecamatan (PWK) Bidang Ekonomi untuk mengentaskan kemiskinan menuju percepatan peningkatan kesejahteraan masyarakat. Melalui program PWK Bidang Ekonomi, pemerintah Kabupaten Temanggung memberikan sejumlah dana modal kerja bergulir kepada kelompok masyarakat miskin di tingkat kecamatan sebagai sarana peningkatan kapasitas dan pemberdayaan masyarakat baik secara individu maupun berkelompok. Dengan menggunakan metode penelitian deskriptif kualitatif, penelitian ini bertujuan menganalisis implementasi program tersebut di Kecamatan Selopampang, Kabupaten Temanggung berdasarkan indikator masukan, proses, luaran, dan dampak. Penelitian ini menemukan bahwa implementasi PWK pada Bidang Ekonomi di Kecamatan Selopampang membantu masyarakat miskin dalam meningkatkan kapasitas ekonomi dan sosial. Penerima manfaat mengaku mengalami peningkatan kemampuan dalam hal memenuhi kebutuhan hidup, mengakses permodalan untuk membangun usaha, dan menampilkan peranan-peranan sosialnya di masyarakat.
\end{abstract}

Kata kunci: dampak ekonomi, implementasi program; program Pagu Wilayah

\begin{abstract}
The Government of the District of Temanggung implements the District Area Budget Ceiling Economic Program (economic PWK) to alleviate poverty towards acceleration of people's welfare improvement. Through the economic PWK, Temanggung Regency government provides a number of revolving working capital funds to poor communities at the district level as a means of capacity building and empowerment of communities both individually and in groups. Using descriptive qualitative research methods, this study aims to analyze the implementation of the program in Selopampang District in Temanggung Regency based on input, process, output, and outcome indicators. This research found that the implementation of economic PWK in Selopampang District, Temanggung District helped the poor in increasing economic and social capacity. Beneficiaries claim experiencing capacity improvement in terms of meeting their daily needs, accessing capital to build a business, and displaying their social roles in the community.
\end{abstract}

Key words: district area economic budget ceiling program (PWK), economy impact, program implementation

\section{Pendahuluan}

Di Indonesia masalah kemiskinan masih menjadi sorotan utama terkait dengan usaha-usaha pemerintah dalam meningkatkan kesejahteraan sosial Indonesia. Secara umum, persentase penduduk miskin menunjukkan tren menurun secara melambat selama periode 2012-2015. Tingkat penurunan kemiskinan yang hanya mencapai 0,3 persen pada tahun 2015 adalah yang terkecil sepanjang periode empat tahun terakhir. Pemerintah telah berhasil menurunkan jumlah penduduk miskin dari 29,13 juta jiwa atau 11,96 persen pada tahun 2012 menjadi 28,59 juta jiwa atau 11,22 persen pada Maret 2015. Meskipun menurun dibandingkan tahun 2012, tetapi semenjak tahun 2013, jumlah penduduk miskin selalu meningkat setiap tahunnya. Di tahun 2015, jumlah penduduk miskin mengalami peningkatan sebanyak 310 ribu jiwa dari tahun 2014 dan 520 ribu jiwa dari tahun 2013. Per Maret 2016 jumlah penduduk miskin Indonesia tercatat sebesar 28,01 juta orang atau mencapai 10,86 persen dari keseluruhan penduduk.

Pemerintah merupakan lembaga yang dipandang paling bertanggungjawab untuk menangani penduduk miskin, sehingga tingginya jumlah dan persentase penduduk miskin sering dikaitkan dengan kegagalan pemerintah dalam menjalankan tugasnya. Dalam konteks ini

\footnotetext{
${ }^{1}$ Dinas Sosial Kabupaten Temanggung. Jawa Tengah (email korespodensi: yunipsdk@gmail.com)

${ }^{2}$ Departemen Pembangunan Sosial dan Kesejahteraan, Universitas Gadjah Mada (agnes_ugm@yahoo.co.id)
} 
Yuni Astuti, Agnes Sunartiningsih - Implementasi Program Pagu Wilayah Kecamatan Bidang Ekonomi untuk Peningkatan Kapasitas Sosial dan Ekonomi Masyarakat di Kabupaten Temanggung

pemerintah telah menempuh berbagai upaya untuk menanggulangi kemiskinan melalui program-program yang dilaksanakan dari instansi pemerintah pusat sampai dengan daerah, namun upaya yang dilakukan belum memberikan hasil yang optimal dikarenakan kemampuan yang dimiliki pemerintah relatif terbatas. Menurut Akyuwen (Suthapa, Wijaya, \& Akyuwen, 2010) faktor lain yang menyebabkan belum optimalnya penanganan kemiskinan adalah kecenderungan program-program pemerintah dilaksanakan secara kurang terkoordinasi, tidak berkesinambungan, sasaran yang tumpang tindih, dan bersifat charity, yaitu melalui pemberian bantuan tanpa syarat kepada penduduk miskin yang memenuhi kriteria tertentu baik dalam bentuk barang maupun uang.

Temanggung adalah salah satu kabupaten di Jawa Tengah dengan penduduk sebanyak 788.264 jiwa pada tahun 2016, dan 134.582 jiwa mengalami permasalahan sosial ber-kaitan dengan keluarga fakir miskin. Upaya-upaya penanggulangan kemiskinan yang dilakukan di Kabupaten Temanggung hingga sekarang masih belum membuahkan hasil yang memuaskan, ketidakberhasilan tersebut dianalisa bersumber dari cara pemahaman dan penanggulangan kemiskinan yang sering diartikan sebagai sebuah kondisi ekonomi semata. Akibat dari pandangan tersebut, proyek pengentasan kemiskinan yang sudah dilakukan hanya sebatas pada upaya perbaikan kondisi ekonomi (peningkatan pendapatan).

Tingkat kemiskinan di kabupaten Temanggung, pada tahun 2013 meningkat dibanding tahun 2012 baik secara jumlah maupun prosentase penduduk miskin yaitu 12,42 persen atau sebesar 91,1 ribu orang. Tingkat kemiskinan pada tahun 2013 ini merupakan tingkat kemiskinan tertinggi selama lima tahun terakhir. Penanganan permasalahan kemiskinan yang cukup kompleks di Kabupaten Temanggung membutuhkan intervensi semua pihak secara bersama dan terkoordinasi, usaha untuk mempercepat penanggulangan kemiskinan juga harus fokus dan berdasarkan kepada potensi yang dimiliki oleh suatu wilayah, berdasarkan kondisi masyarakat yang ada, serta harus melibatkan masyarakat.

Sehubungan dengan hal tersebut, untuk menanggulangi kemiskinan dan meningkatkan efektifitas percepatan pemerataan peningkatan kesejahteraan masyarakat dan pemerataan pembangunan, Pemerintah Daerah Kabupaten Temanggung sejak tahun 2010 telah mengeluarkan sebuah kebijakan yang dikemas dalam Program Pagu Wilayah Kecamatan Bidang Ekonomi yang merupakan pemberian dana hibah oleh pemerintah kepada masyarakat miskin dengan menggunakan kecamatan sebagai lokus pelaksanaan program, sehingga seluruh wilayah kecamatan di Kabupaten Temanggung yang berjumlah 20 kecamatan secara bersamasama melaksanakan Program Pagu Wilayah Kecamatan (PWK) Bidang Ekonomi.

Berdasarkan studi pendahuluan yang di-lakukan oleh penulis, Kecamatan Selopampang adalah salah satu wilayah kecamatan yang sejak program dilaksanakan sampai dengan penelitian ini dilakukan masih tetap eksis melaksanakan program ini sesuai dengan prinsip dasar pelaksanaan Program Pagu Wilayah Kecamatan (PWK) Bidang Ekonomi. Kecamatan Selopampang merupakan salah satu kecamatan di Kabupaten Temanggungyang angka kemiskinannya masih cukup tinggi yaitu sebesar 4.944 jiwa pada tahun 2016. Masalah klasikyang menjadi penghambat utama bagi masyarakat Kecama-tan Selopampang adalah keterbatasan modal. Oleh karena itu, Program Pagu Wilayah Kecamatan (PWK) Bidang Ekonomi sangat cocok diterapkan untuk mempercepat pengentasan kemiskinan di Kecamatan Selopampang Kabupaten Temanggung.

Kondisi yang demikian inilah yang melatar belakangi ketertarikan peneliti untuk melakukan penelitian yang berkaitan dengan Implementasi Program Pagu Wilayah Kecamatan (PWK) Bidang Ekonomi di Kecamatan Selopampang Kabupaten Temangung tersebut. Berangkat dari per-soalan ritual sehingga perlu dicarikan jawaban atas pertanyaan tentang Bagaimana Implementasi Program Pagu Wilayah Kecamatan Bidang Ekonomi di Kecamatan Selopampang Kabupa-ten Temanggung.

Untuk mengetahui jawaban atas persoalan di atas atau dengan kata lain untuk mengetahui implementasi Program Pagu Wilayah Kecamatan (PWK) Bidang Ekonomi di Kecamatan Selopampang Kabupaten Temang-gung maka dapat diketahui jawabannya dengan melihat aspek-aspek atau beberapa indicator yaitu : Indikator Masukan (Input Indicators), Indikator Proses (Process Indicators), Indikator Keluaran/ Hasil Fisik (Output Indicators), Indikator 
Dampak/ Manfaat (Outcames Indicators). Disamping itu penting pula untuk Mengetahui faktor pendukung serta penghambat dalam implementasi Program Pagu Wilayah Kecamatan (PWK) Bidang Ekonomi di Kecamatan Selopampang Kabupaten Temanggung.

\section{Kerangka Teori}

Kemiskinan merupakan masalah sosial yang cukup kompleks, baik dilihat dari aspek sebab maupun aspek akibatnya (Andre, 1996; Barrientos, 2011). Menurut Chambers (dalam Soetomo, 2012) menyatakan bahwa kondisi kemiskinan yang dialami suatu masyarakat sering kali telah berkembang dan bertali-temali dengan berbagai faktor lain yang membentuk jaringan kemiskinan, dimana dalam proses berikutnya dapat memperteguh kondisi kemiskinan itu sendiri. Faktor-faktor yang diindikasi membentuk jaringan atau perangkap kemiskinan tersebut adalah kelemahan fisik, isolasi, kerentanan, dan ketidakberdayaan (Mujiyadi, 2007).

Kemiskinan pada hakikatnya menitik beratkan pada ciri-ciri, faktor penyebab dan dampak yang diakibatkan oleh kemiskinan tersebut. Dengan melihat aspek-aspek tersebut dapat diketahui sejauh mana kemiskinan diderita oleh masyarakat. Sebagaimana John Friedman menyatakan bahwa kemiskinan adalah ketidaksamaan kesempatan untuk mengakumulasikan basis kekuatan sosial (Friedmann,1992). Basis kekuatan sosial meliputi model yang produktif atau asset (misalnya tanah, perumahan, peralatan kesehatan dan lain-lain); sumber-sumber keuangan; organisasi sosial yang dapat digunakan untuk kepentingan bersama; jaringan sosial untuk memperoleh pekerjaan; barang dan lain-lain; pengetahuan dan ketrampilan yang memadai; dan informasi yang berguna untuk memajukan kehidupan (Iskandar, 1995; Kania, J., \& Kramer, 2013).

Dari definisi tersebut, dapat diketahui bahwa kemiskinan tidak hanya berkaitan dengan aspek-aspek material saja, tetapi juga menyangkut aspek non material (Midgley, 1995). Kemiskinan merupakan salah satu permasalahan sosial yang sangat erat kaitannya dengan kebijakan sosial. Sejarah munculnya kebijakan sosial tidak bisa dipisahkan dari hadirnya kemiskinan di dalam masyarakat (Jamsorik, 2009; Subarsono, 2013). Sebagaimana Edi Suharto yang mendefinisikan kemiskinan sebagai masalah sosial yang paling dikenal orang, bahkan banyak yang mengatakan bahwa kemiskinan adalah akar dari masalah sosial (Suharto, 2007b).

Berbagai upaya penanggulangan kemiskinan telah dilakukan di Kabupaten Temanggung sebagai bentuk kebijakan sosial, salah satu upaya untuk menangani permasalahan kemiskinan di Kabupaten Temanggung adalah dengan mengimplementasikan Program Pagu Wilayah Kecamatan Bidang Ekonomi. Menurut Joko Widodo (2006) implementasi merupakan suatu proses yang melibatkan sejumlah sumber yang termasuk manusia, dana dan kemampuan organisasional yang dilakukan oleh pemerintah maupun swasta (individu ataupun kelompok). Proses tersebut dilakukan untuk mencapai tujuan yang telah ditetapkan sebelumnya oleh pembuat kebijakan.

Implementasi kebijakan program perlu memperhatikan Goals yang di dapat. Menurut Stone (dalam Priyono, 2002) menyatakan ada beberapa kategori yang harus ada dalam menentukan goals, yaitu keadilan (equity), efisien (efficiency), keamanan (security), dan kebebasan (liberty). Keadilan (equality) adalah bagaimana cara melihat distribusi kebijakan program dilakukan secara merata. Efisiensi (efficiency) adalah bagaimana cara melihat penggunaan sumber daya yang tepat dan sesuai kebutuhan. Keamanan (security) adalah bagaimana cara melihat pemberian layanan jaminan sosial pada warga lokal. Kebebasan (liberty) adalah cara melihat bagaimana memberikan kesempatan terhadap warga lokal.

Menurut Edi Suharto (2006) sebaik apapun program yang dibuat oleh pemerintah ataupun pembuat kebijakan, tanpa implementasi tentu saja tidak akan berarti apa-apa. Karena perubahan masyarakat yang diharapkan sangat tergantung pada bagaimana program tersebut diaplikasikan dalam berbagai kegiatan nyata. Menurut Edi Suharto (2007a) ada empat prasyarat yang harus di penuhi dalam implementasi program: (1) adanya pengetahuan dan keterampilan untuk melaksanakan program yang telah ditetapkan; (2) tersedianya sumber-sumber yang mendukung pelaksanaan program; (3) adanya sistem dan mekanisme pengontrolan dan pengaturan sumbersumber tersebut; dan (4) adanya pengaturan dan pembagian tugas yang jelas mengenai apa, kapan, bagaimana, dan dimana implementasi program akan dilaksanakan. 
Implementasi kebijakan dipandang dalam pengertian yang lebih luas merupakan alat administrasi hukum dimana berbagai aktor, organisasi, prosedur dan teknik yang bekerja bersama-sama untuk menjalankan kebijakan guna meraih dampak dan tujuan bersama (Lin \& Wong, 2013). James P. Laster dan Joseph Stewart (dalam Winarno, 2007), implementasi pada sisi yang lain merupakan fenomena yang kompleks yang mungkin dapat dipahami sebagai proses, keluaran (output) maupun sebagai hasil.

Dalam penelitian ini, implementasi program pagu wilayah kecamatan bidang ekonomi dilihat dari dari segi input (masukan), Proses, Output (hasil fisik) dan Outcames (manfaat) bagi masyarakat miskin. Program Pagu Wilayah Kecamatan (PWK) merupakan sebuah kebijakan sosial yang diadakan oleh Pemerintah Kabupaten Temanggung bertujuan untuk pemerataan pembangunan antar wilayah kecamatan dan peningkatan pemberdayaan masyarakat. Program yang dilakukan oleh Kabupaten Temanggung ini merupakan program penanggulangan kemiskinan yang dikem-bangkan oleh Pemerintah Kabupaten Temanggung dalam rangka pengentasan permasalahan kemiskinan menuju percepatan kesejahteraan masyarakat, mempercepat per-tumbuhan ekonomi dan pemerataan pembangunan antar wilayah kecamatan berbasis pemberdayaan masyarakat pada suatu wilayah kecamatan.

Program Pagu Wilayah Kecamatan (PWK) merupakan sebuah kebijakan sosial yang diadakan oleh Pemerintah Kabupaten Temanggung bertujuan untuk pemerataan pembangunan antar wilayah kecamatan dan peningkatan pemberdayaan masyarakat. Program yang dilakukan oleh Kabupaten Temanggung ini merupakan program penanggulangan kemiskinan yang dikembangkan oleh Pemerintah Kabupaten Temang-gung dalam rangka pengentasan permasalahan kemiskinan menuju percepatan kesejahteraan masyarakat, mempercepat pertumbuhan ekonomi dan pemerataan pembangunan antar wilayah kecamatan berbasis pemberdayaan masyarakat pada suatu wilayah kecamatan.

Program Pagu Wilayah Kecamatan (PWK) dilaksanakan dengan masyarakat sebagai pelaku utamanya. Program Pagu Wilayah Kecamatan terbagi kedalam dua bidang yaitu Pagu Wilayah Kecamatan Bidang Prasarana Wilayah (PWK) dan Pagu Wilayah Kecamatan (PWK) Bidang Ekonomi. Program Pagu Wilayah Kecamatan (PWK) Bidang Ekonomi adalah satu komponen program pagu wilayah kecamatan yang dialokasikan untuk kegiatan pengembangan, pembinaan, peningkatan, dan pemberdayaan masyarakat ditingkat wilayah kecamatan terutama dipergunakan untuk memberikan akses permodalan kepada pelaku ekonomi produktif.

Program Pagu Wilayah Kecamatan (PWK) Bidang Ekonomi diharapkan mampu menangkap potensi ekonomi masyarakat di wilayah kecamatan untuk dapat membentuk kluster-kluster ekonomi unggulan sesuai karakteristik masing-masing wilayah kecamatan. Program Pagu Wilayah Kecamatan (PWK) Bidang Ekonomi dilaksanakan oleh masyarakat melalui sebuah lembaga yang bernama Komisi Ekonomi Kecamatan (KEK), yang berfungsi sebagai penggerak dan pengelola harian. Tujuan dari lembaga ini adalah untuk mempercepat pertumbuhan ekonomi masyarakat melalui pemberian akses permodalan kepada masyarakat. Akses permodalan diberikan untuk sebuah usaha ekonomi produktif di sektor pertanian, peternakan, perikanan, usaha industri rumah tangga dan industri kecil dan perdagangan kecil. Hal ini sejalan dengan jenis usaha masyarakat dan seluruh potensi ekonomi kerakyatan yang bertumpu pada potensi sumber daya alam dan potensi unggulan daerah.

Menurut Peraturan Daerah Kabupaten Temanggung Nomor 13 Tahun 2011 tentang Sistem Perencanaan Pembangunan Daerah adalah bahwa tujuan dari program PWK Bidang Ekonomi adalah peningkatan pemberdayaan masyarakat miskin dalam berbagai segi yang meliputi kehidupannya, baik dari segi fisik, psikis, pengetahuan dan ketrampilan, kapital dan sosialnya. Dengan keberdayaan yang mereka miliki maka mereka akan mampu menghadapi tantangan hidup terutama masalah kemiskinan yang mereka alami. Pemberdayaan masyarakat miskin diarahkan kepada kemampuan mereka dalam mencapai kondisi sejahtera.

Konsep dalam Program Pagu Wilayah Kecamatan (PWK) Bidang Ekonomi sejalan dengan konsep pemberdayaan yang disampaikan oleh Jim Ife bahwa Program Pagu Wilayah Kecamatan (PWK) Bidang Ekonomi berusaha menyediakan kesempatan, akses, pengetahuan dan ketrampilan untuk 
memperbaiki masa depan mereka, serta berpartisipasi dalam mempengaruhi kehidupan masyarakatnya, seperti disampaikan menurut Jim Ife (2008), pemberdayaan memiliki arti menyediakan sumber daya, kesempatan, kosakata, pengetahuan dan ketrampilan untuk meningkatkan kemampu-an mereka untuk menentukan masa depan sendiri, dan untuk berpartisipasi serta mempengaruhi kehidupan masyarakatnya.

Apabila ditinjau dari konsep kemiski-nan maka kemiskinan dapat dibedakan menjadi beberapa tipe. Menurut Edi Suharto (2006) menyebutkan bahwa tipologi kemiskinan dapat dibedakan menjadi empat tipe yaitu :

a. Kemiskinan absolut adalah keadaan miskin yang diakibatkan oleh ketidakmampuan seseorang atau sekelompok orang dalam memenuhi kebutuhan pokoknya, seperti untuk makan, pakaian, pendidikan, kesehatan, transportasi dll. Seseorang atau sekelompok orang yang kemampuan ekonominya berada dibawah garis kemiskinan, dikategorikan sebagai miskin absolute.

b. Kemiskinan relatif adalah keadaan miskin yang dialami individu atau kelompok dibandingkan dengan kondisi umum suatu masyarakat.

c. Kemiskinan kultural mengacu pada sikap, gaya hidup, nilai, orientasi sosial budaya seseorang atau masyarakat yang tidak sejalan dengan etos kemajuan (masyarakat modern). Sikap malas, tidak memiliki kebutuhan berprestasi (need for echeivement), fatalis, berorientasi ke masa lalu, tidak memiliki jiwa wira usaha.

d. Kemiskinan Struktural adalah kemiskinan yang diakibatkan oleh ketidak beresan atau ketidak adilan struktur, baik struktur politik, sosial, maupun ekonomi yang tidak memungkinkan seseorang atau sekelompok orang menjangkau sumbersumber penghidupan yang sebenarnya tersedia bagi mereka.

Berdasarkan tipologi kemiskinan yang dialami oleh masyarakat, penerima manfaat program Pagu Wilayah Kecamatan (PWK) Bidang Ekonomi adalah kemiskinan yang berdimensi struktural dimana masyarakat miskin kurang memiliki kesempatan untuk memperoleh akses dari berbagai sumber yang dibutuhkan untuk peningkatan kesejahteraan sosial mereka. Pagu Wilayah Kecamatan (PWK) Bidang Ekonomi merupakan suatu program yang ditujukan untuk memperoleh kemudahan akses ekonomi (modal usaha) tanpa agunan dengan tetap mendorong tanggungjawab bersama sehingga diharapkan mereka mampu mengembangkan kegiatan usahanya untuk peningkatan kesejahteraan sosial.

Sementara itu, indikator implementasi yang dapat digunakan dalam Program Pagu Wilayah Kecamatan (PWK) Bidang Ekonomi yang dilaksanakan melalui lembaga Komisi Ekonomi Kecamatan (KEK) seperti yang disampaikan oleh Direktorat Jendral Pemberdayaan Sosial Direktorat Pemberdayaan Fakir Miskin (2009) di dalam buku pedoman umum program pemberdayaan fakir miskin yaitu:

a. Input (masukan) Indikator masukan/ input mengukur kuantitas dan kualitas Sumber Daya Manusia pelaksana, dukungan keuangan untuk pelaksanaan program, peralatan yang dibutuhkan untuk mendukung operasionalisasi dan kelancaran (mesin ketik, komputer, buku-buku) yang dibutuhkan untuk mendukung program, bahan-bahan, pemasaran (sosialisasi program) dan cara pengelolaan lembaga

b. Proses : meliputi bagaimana proses untuk mendapatkan dukungan keuangan, proses perekrutan SDM pengelola/pelaksana dan bagaimana pengembangan SDMnya.

c. Output (hasil Fisik) : menyangkut dua hal, pertama hasil fisik dari pelaksanaan program, apakah dapat berjalan dengan baik, mampu mengembangkan kegiatannya, dapat memenuhi kebutuhan anggotanya serta tidak menyimpang dari tujuan yang telah ditetapkan. Kedua, hasil fisik bagi para penerima manfaat yaitu apakah lembaga/pelaksana program dapat memenuhi kebutuhan modal usahanya sehingga kegiatan usaha yang dilakukan oleh penerima manfaat dapat berjalan dan Hasil fisik menyangkut dua hal, hasil fisik dari pelaksanaan program, apakah dapat berjalan dengan baik, mampu mengembangkan kegiatannya, dapat memenuhi kebutuhan anggotanya serta tidak menyimpang dari tujuan yang telah ditetapkan. Kedua, hasil fisik bagi para penerima manfaat yaitu apakah lembaga/pelaksana program dapat memenuhi kebutuhan modal usahanya 
sehingga kegiatan usaha yang dilakukan oleh penerima manfaat dapat berjalan dan Hasil fisik menyangkut dua hal, hasil fisik dari pelaksanaan program, apakah dapat berjalan dengan baik, mampu mengembangkan kegiatannya, dapat memenuhi kebutuhan anggotanya serta tidak menyimpang dari tujuan yang telah ditetapkan. Kedua, hasil fisik bagi para penerima manfaat yaitu apakah lembaga/pelaksana program dapat memenuhi kebutuhan modal usahanya sehingga kegiatan usaha yang dilakukan oleh penerima manfaat dapat berjalan dan

d. Outcame (manfaat): Mengukur gambaran dan kebermanfaatan yang diperoleh dan mencerminkan keberfungsian sosial para anggotanya dan masyarakat miskin pada umumnya. Misalnya meningkatkan kemampuan fakir miskin dalam pemenuhan kebutuhan pangan dan sandang, meningkatnya taraf pendidikan, kesehatan dan mampu mengakses sumber dari luar.

\section{Metode}

Perlu dijelaskan di sini bahwa jenis penelitian yang dilakukan adalah penelitian deskriptif dengan menggunakan pendekatan kualitatif. Lokasi penelitian ini adalah di Kecamatan Selopampang Kabupaten Temanggung, dengan unit analisis adalah penerima Program Pagu Wilayah Kecamatan (PWK) Bidang Ekonomi yang ada di Kecamatan Selopampang Kabupaten Temanggung. Informan dalam penelitian ini terdiri dari para birokrat terkait program, dan 11 orang penerima manfaat program yang terdiri dari 5 kluster ekonomi produktif di Kecamatan Selopampang yang merasakan dampak atau manfaat dari adanya Program Pagu Wilayah Kecamatan (PWK) Bidang Ekonomi.

Teknik pengumpulan data yang digunakan dalam penelitian ini adalah dengan tehnik observasi, wawancara dan studi dokumentasi. Dalam penelitian ini, data dianalisa secara deskriptif dengan pendekatan kualitatif. Penelitian secara deskriptif ini dimaksudkan untuk mendiskripsikan data penelitian sesuai dengan variabel-variabel yang diteliti, tanpa melakukan pengujian hipotesa. Adapun teknik yang digunakan adalah teknik interaktif dari Miles \& Huberman (2014). Dalam model analisis data terdiri atas tiga komponen yaitu reduksi data, penyajian data, dan penarikan kesimpulan.
Ketiga komponen tersebut aktifitasnya berbentuk interaktif dengan proses siklus. Adapun teknik uji keabsahan datanya melalui cara peningkatan ketekunan dan triangulasi.

\section{Hasil}

Indikator Masukan (Input Indicators) Implementasi Program

Guna melihat Indikator Masukan (Input Indicators) Implementasi Program Pagu Wilayah Kecamatan (PWK) maka akan dibahas kedalam beberapa aspek yaitu, Sumber Daya Manusia (SDM), struktur organisasi pengelola, dukungan anggaran, serta peralatan dan bahan. Faktor sumber daya mempunyai peranan penting dalam implementasi kebija-kan. Sumber Daya Manusia merupakan salah satu variabel yang mempengaruhi keberhasilan pelaksanaan sebuah program atau sebuah kebijakan. Untuk menjelaskan faktor sumber daya manusia terdapat dua hal akan dijelaskan, tahapan pemilihan anggota dan penerima manfaat program.

Berdasarkan hasil penelitian di lapangan, tahapan pemilihan pengelola Program Pagu Wilayah Kecamatan (PWK) Bidang Ekonomi di Kecamatan Selopampang melalui tahapan seleksi administrasi, ujian tertulis dan wawancara. Tahap input (masukan) yang berkaitan dengan Sumber Daya Manusia dari pengelola program sudah dilalui berdasarkan proses yang selektif untuk mendapatkan sumber daya manusia yang berkualitas. Meskipun terjadi pergantian kepengurusan namun tidak berdasarkan pada seleksi secara resmi namun penggantinya sudah ditentukan oleh pejabat yang ada di lingkungan kecamatan tersebut.

Sementara itu terkait penerima manfaat Program Pagu Wilayah Kecamatan (PWK) Bidang Ekonomi di Kecamatan Selopampang memiliki beberapa persyaratan yaitu masyarakat miskin yang memiliki kegiatan usaha ekonomis produktif (economically active working poor), jadi tidak semua masyarakat miskin memiliki kesempatan dalam memanfaatkan program pemerintah ini. Program Pagu Wilayah Kecamatan (PWK) Bidang Ekonomi yang ada di Kecamatan Selopampang ternyata belum mampu memberikan kesempatan yang sama terhadap masyarakat

Dari hasil penelitian dilapangan dapat diketahui bahwa untuk implementasi Program Pagu Wilayah Kecamatan (PWK) Bidang Ekonomi 
di Kecamatan Selopampang, tahap input (masukan) yang berkaitan dengan penerima manfaat program adalah bahwa tidak semua masyarakat miskin memiliki kesempatan untuk menjadi penerima manfaat program ini, yaitu hanya masyarakat yang dikategorikan miskin namun memiliki kegiatan ekonomi (economically active working poor) seperti pertanian, perikanan, peternakan, industri rumah tangga, kerajinan, pertukangan, perdagangan, dan lain-lain. Namun demikian, dari beberapa pernyataan tersebut diatas, berdasarkan hasil penelitian di lapangan Program Pagu Wilayah Kecamatan (PWK) Bidang Ekonomi yang ada di Kecamatan Selopampang ternyata belum mampu memberikan kesempatan yang sama terhadap masyarakat miskin dalam mengakumulasikan basis kekuatan sosial dan sumber-sumber keuangan yang ada di masyarakat.

Faktor lain yang dapat mempengaruhi tingkat keberhasilan sebuah implementasi program adalah adanya struktur birokrasi, atau lebih sederhananya disebut dengan struktur organisasi. Sesuai dengan hasil penelitian, struktur organisasi pengelola Program Pagu Wilayah Kecamatan (PWK) Bidang Ekonomi, dalam hal ini adalah lembaga Komisi Ekonomi Kecamatan (KEK) Tim fasilitasi kecamatan dalam KEK merupakaan pejabat struktural yang ada di wilayah kecamatan. Berdasarkan hasil penelitian di lapangan, bahwa tim fasilitasi kecamatan belum bisa berperan secara maksimal karena seringnya pergantian personil dalam jabatan struktural di Kecamatan Selopampang.

Faktor berikutnya yang mempengaruhi implementasi program ialah terkait dukungan keuangan. Pengelola Pagu Wilayah Kecamatan (PWK) Bidang Ekonomi memperoleh dana operasional untuk melaksanakan kewenangan dan tugasnya. Besarnya dana operasional adalah 10 persen (\%) dari pagu indikatif Program Pagu Wilayah Kecamatan (PWK) Bidang Ekonomi pada tahun berjalan. Dalam implementasi Program Pagu Wilayah Kecamatan (PWK) Bidang Ekonomi di Kecamatan Selopampang, tahap input (masukan) yang berkaitan dengan dukungan keuangan, pengelola memang memiliki anggaran yang dapat dimanfaatkan untuk operasional kantor, termasuk untuk honor para pengelola, namun jumlahnya sangat sedikit sehingga kurang mencukupi jika untuk memenuhi segala kegiatan implemen-tasi program yang membutuhkan dukungan keuangan.
Faktor ketiga ialah peralatan adalah alat-alat yang dibutuhkan untuk mendukung operasional dan kelancaran program PWK Bidang Ekonomi seperti mesin ketik, komputer, laptop, buku-buku administrasi. Peralatan yang ada selama ini sebenarnya masih kurang, Peralatan yang paling dibutuhkan untuk operasional yaitu penamba-han komputer, karena selama ini hanya ada satu komputer. Para pengelola juga kurang memahami tentang perangkat dan programnya sehingga apabila terjadi kerusakan pada komputer dan membutuhkan perbaikan dalam waktu yang cukup lama maka akan mengganggu pelayanan dan pengadministrasian dalam data komputer. Sementara itu yang dimaksud dengan bahan adalah bahan yang dipakai untuk memperlancar pelaksa-naan program seperti gedung/sekertariat, meja kerja, listrik, air dan bahan-bahan lainnya. Bahan yang berupa sarana dan prasarana untuk operasional pengelola program PWK Bidang Ekonomi masih belum terpenuhi, yang menjadi prioritas kebutuhan adalah gedung kantor yang tetap dan milik sendiri.

\section{Indikator Proses (Process Indicators) Implementasi Program}

Agar kesinambungan kegiatan program dapat terjaga di masyarakat, maka dalam pelaksanaan program PWK Bidang Ekonomi ada modal kerja yang disebut dengan Dana Modal Kerja Bergulir (DMKB) sebagai modal usaha yang langsung diberikan kepada penerima manfaat program PWK Bidang Ekonomi. Sistem dana bergulir dimaksudkan agar penerima manfaat tidak selamanya bergantung pada siapapun dan disisi lain bagi pihak pemerintah untuk tidak selamanya memberikan subsidi kepada penerima manfaat.

Masyarakat miskin dapat mengajukan proposal untuk mendapatkan Dana Modal Kerja Bergulir (DMKB) dengan persyaratan memiliki kegiatan usaha ekonomi yang memiliki potensi produktif seperti pertanian, perikanan, peternakan, industri rumah tangga, kerajinan, pertukangan, perdagangan. Imple-mentasi Program Pagu Wilayah Kecamatan (PWK) Bidang Ekonomi di Kecamatan Selopampang, tahap proses yang berkaitan dengan proses untuk mendapatkan dana modal kerja bergulir di Kecamatan Selopampang belum memberikan akses yang seluas-luasnya kepada kelompok masyarakat miskin, hanya masyarakat miskin 
Yuni Astuti dan Agnes Sunartiningsih - Implementasi Program Pagu Wilayah Kecamatan Bidang Ekonomi untuk Peningkatan Kapasitas Sosial dan Ekonomi Masyarakat di Kabupaten Temanggung

yang memiliki usaha yang dapat mengakses DMKB yang dikelola oleh program Pagu Wilayah Kecamatan (PWK) Bidang Ekonomi di Kecamatan Selopampang ini.

Dalam sosialisasi program, pengelola bersikap pro aktif dan dinamis. Pengelola mendatangi calon penerima manfaat. Pengelola mendatangi desa dan menggali informasi sebanyak-banyaknya melalui perangkat desa untuk mengetahui calon sasaran dalam kegiatan sosialisasi program. Kemudian calon sasaran terpilih diundang untuk mendengarkan sosialisasi dari pengelola berkaitan dengan Program Pagu Wilayah Kecamatan (PWK) Bidang Ekonomi.

Pelaksanaan sosialisasi program hanya dilakukan satu kali untuk masing-masing desa dan dilaksanakan pada saat di awal program saja, dengan tidak memberikan sosialisasi kepada seluruh masyarakat miskin yang ada di Kecamatan Selopampang, hanya masyarakat miskin yang sudah memiliki usaha yang diberi sosialisasi. Program Pagu Wilayah Kecamatan (PWK) Bidang Ekonomi belum bisa memberikan akses informasi kepada seluruh masyarakat miskin yang ada di Kecamatan Selopampang, akses permodalan hanya diberikan kepada masyarakat miskin yang memiliki usaha ekonomis produktif atau embrio usaha ekonomis produktif.

Program PWK Bidang Ekonomi banyak berperan sebatas lembaga keuangan mikro, belum pada tahap pendampingan, karena memang tenaga yang ada tidak mencukupi dan pengetahuannya masih sebatas apa adanya. Tenaga-tenaga yang ada di Program PWK Bidang Ekonomi Kecamatan Selopampang bukanlah tenaga yang memahami tentang pemberdayaan masyara-katataupun pengembangan masyarakat lokal. Pendampingan program PWK Bidang Ekonomi belum mendayagunaan sumbersumber yang ada pada masyarakat serta belum menekankan pada prinsip partisipasi sosial. Anggota masyarakat atau kelompok penerima manfaat program masih dipandang sebagai masyarakat yang bermasalah (masyarakat miskin).

Proses pengelolaan alat dan bahan sudah diatur dalam Anggaran Dasar dan Anggaran Rumah Tangga (AD/ART) pada lembaga KEK. Salah satu contoh apabila ada peralatan dan bahan yang rusak dan memerlukan biaya yang cukup besar diambilkan dari dana operasional yang ada, namun demikian pengurus masih merasa belum mencukupi atas pengelolaan sarana prasarana yang ada untuk mendukung implementasi program Pagu Wilayah Kecamatan (PWK) Bidang Ekonomi di Kecamatan Selopampang.

\section{Indikator Keluaran /Hasil Fisik (Output Indicators) Implementasi Program \\ Hasil fisik yang didapat adalah} terpenuhinya kebutuhan modal usaha untuk mengembangkan kluster-kluster unggulan yang ada di wilayahnya sehingga kegiatan anggota dapat berjalan dan berkembang, pendapatan anggota juga bertambah, kesejahteraaan anggota menjadi meningkat sehingga penerima manfaat dapat meningkatkan kemampuan diri dalam memenuhi kebutuhan-kebutuhan hidupnya. Program PWK Bidang Ekonomi untuk saat ini masih sebatas memenuhi kebutuhan modal usaha anggotanya saja, belum menambah jenis usaha bagi anggotanya. Hal tersebut lebih disebabkan kepada keterbatasan kemampuan pengelola dan penerima manfaat program itu sendiri. Disamping itu, juga adanya ketakutan dari anggota untuk menambah jenis usaha yang dilakukannya. Ketakutan tersebut berupa kekhawatiran apabila dagangan atau jenis usaha barunya tidak laku di pasaran dan berdampak pada kemampuan pembayaran setoran atas dana modal kerja bergulir (DMKB) yang dipinjamnya.

Dari beberapa temuan di lapangan menunjukan bahwa Program Pagu Wilayah Kecamatan (PWK) Bidang Ekonomi Program Pagu Wilayah Kecamatan (PWK) Bidang Ekonomi tidak saja memberikan manfaat secara ekonomi namun juga memberikan manfaat secara sosial bagi anggotanya. Misalnya meningkatnya nilai-nilai kebersamaan, kegotong-royongan, saling membantu, saling perduli, perasaan senasib sepenang-gungan, perasaan untuk maju bersama-sama dalam mengatasi permasalahan kemiskinan. Namun program tersebut secara garis besar belum mampu mengentaskan kemiskinan yang terjadi dalam masyarakat karena ternyata program ini tetap memposisikan masyarakat miskin berada dalam aliensi, akses yang rendah terhadap kekuasaan, dan akses permodalan dan tetap berada pada pilihanpilihan hidup yang sempit. 


\section{Indikator Dampak/Manfaat(Outcame Indicators) Implementasi Program}

Indikator dampak merupakan hasil, akibat atau manfaat yang ditimbulkan dari adanya Program Pagu Wilayah Kecamatan (PWK) Bidang Ekonomi di Kecamatan Selopampang Kabupaten Temanggung. Program Pagu Wilayah Kecamatan Bidang Ekonomi memberikan kontribusi positif terhadap kehidupan masyarakat di Kecamatan Selopampang. Dalam mengkaji implementasi program PWK Bidang Ekonomi di Kecamatan Selopampang, maka perlu untuk melihat sejauhmana program yang berjalan dapat memberikan manfaat (Outcame) bagi masyarakat, khususnya penerima manfaat program. Dengan mengetahui kontribusi positif yang diberikan oleh sebuah program kepada masyarakat, maka dapat menjadi contoh baik (good practice) untuk pelaksanaan program-program penanggulangan kemiski-nan selanjutnya.

Manfaat yang diharapkan bagi para penerima program PWK Bidang Ekonomi adalah dapat meningkatnya kemampuan penerima manfaat dalam memenuhi kebu-tuhan hidup yang diperlukan dan meningkatnya kemampuan penerima manfaat program dalam melaksanakan/ menampilkan peranan-peranan sosialnya di masyarakat. Dalam proses wawancara, masyarakat mengakui bahwa dengan menjadi anggota KEK mereka merasakan adanya banyak manfaat bagi masyarakat di Kecamatan Selopampang. Secara rinci manfaat yang dirasakan pertama berkaitan dengan peningkatan kemampuan penerima manfaat dalam memenuhi kebutuhan hidup dan melaksanakan peranan sosialnya. Pada sisi sosial masyarakat keberadaan PWK Bidang Ekonomi memberi penguatan hubungan sosial, kesetiakawanan sosial, dan penyelesaian masalah sosial.

\section{Diskusi}

Dalam implementasi Program Pagu Wilayah Kecamatan (PWK) Bidang Ekonomi, pemerintah berusaha memberikan kebebasan kepada masyarakat untuk dapat menentukan hal-hal yang menjadi kebutuhan mereka. Masyarakat dilatih untuk menentukan kebutuhan mereka sendiri. Pemerintah dalam hal ini lebih berperan sebagai fasilitator yang memberikan fasilitas kepada masyarakat untuk penentuan kebutuhannya sendiri. Melalui Program PWK Bidang Ekonomi, penerima manfaat diberi kebebasan untuk menentukan sendiri jenis usaha yang akan digelutinya, kebutuhan-kebutuhan yang mendukung kegiatan usahanya. Pemerintah melalui Program PWK Bidang Ekonomi hanya mejadi fasilitator agar masyarakat miskin memiliki keberdayaan dalam pemenuhan kebutuhan mereka.

Pemberdayaan dilahirkan dari bahasa Inggris, yakni empowerment yang mempunyai makna dasar pemberdayaan, di mana daya bermakna kekuatan (power). Sedangkan dalam kajian ini pengertian "pemberdayaan" dimaknai sebagai segala usaha untuk membebaskan masyarakat miskin dari belenggu kemiskinan yang menghasilkan suatu situasi di mana kesempatan-kesempatan ekonomis tertutup bagi mereka, karena kemiskinan yang terjadi tidak bersifat alamiah semata, melainkan hasil berbagai macam faktor yang menyangkut kekuasaan dan kebijakan, maka upaya pemberdayaan juga harus melibatkan kedua faktor tersebut.

Titik fokus konsep pemberdayaan adalah lokalitas, sebab civil society menurut masyarakat akan merasa siap diberdayakan melalui isu-isu lokal. Tentunya dengan tidak mengabaikan kekuatan-kekuatan ekonomi dan struktur di luar civil society tersebut. Target dari konsep pemberdayaan dalam Program PWK Bidang Ekonomi di Kecamatan Selopampang ini adalah ingin mengubah kondisi yang serba sentralistik menjadi situasi yang lebih otonom dengan cara memberikan kesempatan kepada kelompok masyarakat miskin, masyarakat yang kurang mampu dalam banyak aspek kehidupan untuk merencanakan dan melaksanakan program pembangunan yang mereka pilih sendiri.

Dalam konsep pemberdayaan ini, masyarakat dipandang sebagai subyek yang dapat melakukan perubahan, oleh karena diperlukan pendekatan yang lebih dikenal dengan singkatan ACTORS, sebagai berikut:

a. Authority atau wewenang pemberdayaan dilakukan dengan memberikan kepercayaan kepada masyarakat untuk melakukan perubahan yang mengarah pada perbaikan kualitas dan taraf hidup mereka.

$b$. Confidence and compentence atau rasa percaya diri dan kemampuan diri, pemberdayaan dapat diawali dengan menimbulkan dan memupuk rasa percaya diri serta melihat kemampuan bahwa masyarakat sendiri dapat melakukan perubahan. 
c. Truth atau keyakinan, untuk dapat berdaya, masyarakat atau seseorang harus yakin bahwa dirinya memiliki potensi untuk dikembangkan.

d. Opportunity atau kesempatan, yakni memberikan kesempatan kepada masyarakat untuk memilih segala sesuatu yang mereka inginkan sehingga dapat mengembangkan diri sesuai dengan potensi yang mereka miliki.

e. Responsibility atau tanggung jawab, maksudnya yaitu perlu ditekankan adanya rasa tanggung jawab pada masyarakat terhadap perubahan yang dilakukan.

$f$. Support atau dukungan, adanya dukungan dari berbagai pihak agar proses perubahan dan pemberdayaan dapat menjadikan masyarakat lebih baik.

Dalam analisis ini, masyarakat miskin atau yang berada pada posisi belum termanfaatkan secara penuh potensinya akan meningkat bukan hanya ekonominya, tetapi juga harkat, martabat, rasa percaya diri, dan harga dirinya. Dengan demikian, dapatlah diartikan bahwa pemberdayaan masyarakat yang dilakukan melalui Program PWK Bidang Ekonomi adalah sebuah konsep pembangunan ekonomi yang merangkum nilai-nilai sosial. Pemberdayaan masyarakat bukan membuat masyarakat menjadi makin tergantung pada berbagai program pemberian karena pada dasarnya setiap apa yang dinikmati, harus dihasilkan atas usaha sendiri (yang hasilnya dapat dipertukarkan dengan pihak lain).

Dengan demikian, tujuan akhirnya adalah memandirikan masyarakat, memampu-kan, dan membangun kemampuan untuk memajukan diri ke arah kehidupan yang lebih baik secara berkesinambungan. Upaya pengentasan kemiskinan yang dilakukan oleh pemerintah Kabupaten Temanggung melalui Program PWK Bidang Ekonomi, khususnya di Kecamatan Selopampang ini dengan memberikan akses yang lebih luas kepada masyarakat miskin menjadi produktif, dimana lembaga KEK memberikan jasa intermediasi lembaga pemberdayaan, termasuk usaha produktif yang dilakukan oleh masyarakat miskin. Dengan adanya program ini masyarakat merasa sangat terbantu dengan modal untuk mengembangkan usaha dan meningkatkan kesejahteraan mereka.

\section{Kesimpulan}

Dari beberapa temuan di lapangan menunjukan bahwa Program Pagu Wilayah Kecamatan (PWK) Bidang Ekonomi Program Pagu Wilayah Kecamatan (PWK) Bidang Ekonomi tidak saja memberikan manfaat secara ekonomi namun juga memberikan manfaat secara sosial bagi anggotanya. Misalnya meningkatnya nilainilai kebersamaan, kegotong-royongan, saling membantu, saling perduli, perasaan senasib sepenang-gungan, perasaan untuk maju bersamasama dalam mengatasi permasalahan kemiskinan. Namun program tersebut secara garis besar belum mampu mengentaskan kemiskinan yang terjadi dalam masyarakat karena ternyata program ini tetap memposisikan masyarakat miskin berada dalam aliensi, akses yang rendah terhadap kekuasaan, dan akses permodalan dan tetap berada pada pilihan-pilihan hidup yang sempit. Kemiskinan merupakan permasalahan yang bersifat multidimensional yang tidak mungkin terselesaikan hanya dengan Program Pagu Wilayah Kecamatan (PWK) Bidang Ekonomi.

Program Pagu Wilayah Kecamatan (PWK) Bidang Ekonomi yang ada di Kecamatan Selopampang memang dapat membantu bagi para penerima manfaat program untuk memperoleh kemudahan dalam mengakses sistem sumber ekonomi, namun dalam kenyataanya Program Pagu Wilayah Kecamatan (PWK) Bidang Ekonomi masih belum dapat memberikan akses seluasluasnya kepada seluruh masyarakat miskin, hanya masyarakat miskin yang memiliki usaha ekonomis produktif yang dapat mengakses program ini. Pada sisi yang lain realita yang terjadi adalah masih adanya ketidaksamaan kesempatan untuk masyarakat miskin di Kecamatan Selopampang untuk mengakumu-lasikan basis-basis kekuatan sosial.

Secara garis besar program ini belum mampu mengentaskan kemiskinan yang terjadi dalam masyarakat karena kemiskinan merupakan permasalahan yang bersifat multidimensional yang tidak mungkin terselesaikan hanya dengan Program Pagu Wilayah Kecamatan (PWK) Bidang Ekonomi. Program Pagu Wilayah Kecamatan (PWK) Bidang Ekonomi yang ada di Kecamatan Selopampang memang dapat membantu bagi para penerima manfaat program untuk memperoleh kemudahan dalam mengakses sistem sumber ekonomi, namun dalam kenyataanya belum dapat memberikan akses seluas-luasnya kepada seluruh masyarakat miskin. 
Dalam menanggulangi permasalahan kemiskinan diperlukan penguatan kapasitas individu/ kelompok masyarakat miskin. Perlu adanya pemberian motivasi dan pelatihan bagi penerima manfaat sehingga diharapkan dapat memunculkan ide-ide pengembangan usaha baru dan kerjasama serta partisipasi dari penerima manfaat menjadi meningkat. Tentunya ini dengan harapan pemberdayaan yang dilakukan tidak saja menyangkut aspek ekonomi tetapi juga aspek sosial. Aspek sosial tidak dapat berjalan dengan baik bila tidak didukung oleh aspek ekonomi yang kuat, seperti usaha yang berkembang, pendapatan yang meningkat, dan lain-lain. Akan tetapi sebaliknya, aspek ekonomi tidak akan berarti apa-apa bila tidak didukung dengan kegiatan-kegiatan sosial yang baik, seperti kerja sama diantara mereka, keperdulian, rasa saling tolong menolong diantara mereka.

Di sisi yang lain agar kebermanfaatan program terus meningkat, maka diperlukan pengembangan kapasitas pengelola (capacity building) melalui penambahan tarining atau pelatihan-pelatihan yang berkaitan dengan pemberdayaan masyarakat, penggalangan dukungan, pemanfataan sumber-sumber yang ada, karena dalam pelaksanaan programprogram penanggulangan kemiskinan diperlukan pemahaman mengenai kompleksitas permasalahan kemiskinan dan pengenalan sumber daya atau kekuatan yang dapat dikerahkan dan disinergikan dalam mengatasi kemiskinan secara lebih komprehensif dan berkelanjutan.

Dalam Implementasi Program Pagu Wilayah Kecamatan (PWK) Bidang Ekonomi masih terdapat beberapa ketidaksesuaian, dalam hal input dan proses. Program Pagu Wilayah Kecamatan (PWK) Bidang Ekonomi untuk saat ini masih sebatas memenuhi kebutuhan modal usaha bagi masyarakat miskin yang memiliki usaha ekonomi produktif saja, belum semua masyarakat miskin mampu mengakses program ini. Program Pagu Wilayah Kecamatan (PWK) Bidang Ekonomi sampai saat ini juga belum bisa menambah jenis usaha bagi anggotanya. Hal tersebut lebih disebabkan kepada keterbatasan kemampuan anggota atau penerima manfaat dari Pagu Wilayah Kecamatan (PWK) Bidang Ekonomi untuk mengembangkan jenis usahanya. Namun demikian tetap tidak dapat dipungkiri bahwa program ini sangat dibutuhkan dan juga sangat bermanfaat pagi para penerima program.
Guna keberlanjutan program agar menjadi program penanggulangan kemiski-nan yang berkelanjutan perlu adanya tambahan sumber daya manusia yang handal, yang profesional dalam melakukan pendampingan. Masyarakat miskin seharus-nya tidak dipandang sebagai masyarakat yang bermasalah melainkan perlu dipandang sebagai masyarakat yang unik dan memiliki potensi, hanya saja potensi tersebut belum sepenuhnya dikembangkan. Pendamping program diharapkan dapat membantu meningkatkan kesadaran dan mengembangkan kemampuan masyarakat dalam mencapai tujuan-tujuan yang di harapkan.

Dilihat dari kebermanfaatan Program Pagu Wilayah Kecamatan (PWK) Bidang Ekonomi, dapat diketahui melalui output (hasil fisik) dan Outcame (manfaat). Hasil fisik bagi Program Pagu Wilayah Kecamatan (PWK) Bidang Ekonomi yaitu terlihat dari perkembangan Dana Modal Kerja Bergulir (DMKB) yang ada yang pada awal berdirinya berjumlah Rp. 487.653.000,- setelah 6 tahun melaksanakan kegiatan operasional bertam-bah menjadi Rp. 557.718.819,--Sedangkan hasil fisik bagi penerima manfaat yaitu penerima manfaat mendapat kemudahan untuk mengakses permodalan sebagai sistem sumber ekonomi dan sosial dengan cara yang sangat mudah dan dekat dengan tempat tinggal mereka. Program Pagu Wilayah Kecamatan (PWK) Bidang Ekonomi di Kecamatan Selopampang telah berhasil membangkitkan kegiatan ekonomi bagi kelompok masyarakat miskin yang ada di wilayah di Kecamatan Selopampang, namun keberlanjutan (sustainability) dari program ini tanpa dukungan dari pihak luar yang terus menerus masih dipertanyakan.

Program Pagu Wilayah Kecamatan (PWK) Bidang Ekonomi tidak saja memberikan manfaat secara ekonomi namun juga memberikan manfaat secara sosial bagi anggotanya. Misalnya meningkatnya nilai-nilai kebersamaan, kegotongroyongan, saling membantu, saling perduli, perasaan senasib sepenanggungan, perasaan untuk maju bersama-sama dalam mengatasi permasala-han kemiskinan. Agar kebermanfaatan program terus meningkat, maka diperlukan pengembangan kapasitas pengelola (capacity building) melalui penambahan tarining atau pelatihan-pelatihan yang berkaitan dengan strategi-strategi pemberdayaan masyarakat, pengembangan ekonomi mikro dan kelembagaan ekonomi rakyat. 
Untuk mengatasi legal status agar jelas, keberadaan Lembaga Komisi Ekonomi Kecamatan (KEK) sebagai lembaga pengelola Program Pagu Wilayah Kecamatan (PWK) Bidang Ekonomi kedepan perlu diarahkan menjadi sebuah lembaga keuangan mikro yang dapat diposisikan sebagai energi pemberdayaan usaha ekonomis produktif, terutama untuk peningkatan kesejahteraan lapisan masyarakat bawah. Dengan mengacu kepada hasil penelitian ini, perlu kiranya dilakukan penelitian lanjutan yang lebih mendalam untuk memperoleh faktor-faktor apa yang dapat mempengaruhi keberlanjutan (sustainability) Program Penanggulangan Kemiskinan di Kabupaten Temanggung dan penelitian yang lebih mendalam untuk memperoleh faktor-faktor dominan yang sekiranya dapat mempengaruhi kesejahteraan masyarakat Kabupaten Temanggung melalui usaha-usaha bersama dalam bidang ekonomi.

\section{Acknowledgement}

Artikel ini merupakan hasil penulisan ringkas tesis penulis yang telah diuji dan dinyatakan lulus untuk meraih gelas Master of Arts dari Departemen Pembangunan Sosial dan Kesejahteraan (PSdK), Fakultas Ilmu Sosial dan Ilmu Politik, Universitas Gadjah Mada pada tahun 2018.

\section{Referensi}

Andre, A. (1996). Kemiskinan dan strategi memerangi kemiskinan. Yogyakarta: Liberty.

Astuti, Y., Suyatna, H., \& Sunartiningsih, A., (2018) Implementasi Program Pagu Wilayah Kecamatan Bidang Ekonomi di Kecamatan Selopampang, Kabupaten Temanggung. Tesis, Universitas Gadjah Mada.

Barrientos, A. (2011). Social protection and poverty. International Journal of Social Welfare, 3(20), 240-249. https://doi. org/https://doi.org/10.1111/j.14682397.2011.00783.x

Friedmann, J. (1992). Empowerment: The politics of alternative development. USA: John Wiley \& Sons Ltd.

Ife, J., \& Tesoriero, F. (2008). Alternatif pengembangan masyarakat di era globalisasi community development. Yogyakarta: Pustaka Pelajar.
Iskandar, J. (1995). Strategi dasar membangun kekuatan masyarakat. Bandung: Koperasi STKS.

Jamsorik, A. (2009). Social policy in the postwelfare state: Australian society in a changing world (3rd ed.). Adelaide: Pearson Australia Group Pty Ltd.

Kania, J., \& Kramer, M. (2013). Collective impact. Retrieved from Stanford Social Innovation Review website: https://ssir.org/articles/ entry/collective_impact

Lin, K., \& Wong, K. (2013). Social policy and social order in East Asia: An evolutionary view. Asia Pacific Journal of Social Work and Development, 23(4), 270-284.

Midgley, J. (1995). Social development. California: British Liberty Cataloguing in Publication.

Miles, B., Huberman, M., \& Saldana, J. (2014). Qualitative data analysis: A method source book (Third). California: SAGE Publication Inc.

Mujiyadi, B. (2007). Implementasi program pemberdayaan fakir miskin: Studi evaluasi di delapan daerah di Indonesia. Jakarta: Departemen Sosial RI.

Priyono, E. (2002). Situasi ketenagakerjaan Sumedang dan tinjauan kritis. Jurnal Analisis Sosial, 7(1), 1-15.

Soetomo. (2012). Keswadayaan masyarakat: Manifestasi kapasitas masyarakat untuk berkembang secara mandiri. Yogyakarta: Pustaka Pelajar.

Subarsono, G. (2013). Analisis kebijakan publik: Konsep, teori, dan aplikasi. Yogyakarta: Pustaka Pelajar.

Suharto, E. (2006). Analisis kebijakan publik: Panduan praktis mengkaji masalah dan kebijakan sosial. Bandung: Alfabeta.

Suharto, E. (2007a). Kebijakan sosial sebagai kebijakan publik. Bandung: Alfabeta.

Suharto, E. (2007b). Pembangunan, kebijakan sosial, dan pekerjaan sosial: Spektrum pemikiran. Bandung: LSP-STKS.

Suthapa, D., Wijaya, K., \& Akyuwen, R. (2010). Teori dan praktik keuangan mikro di Indonesia. Yogyakarta: Sekolah Pascasarjana UGM.

Widodo,J. (2006). Analisis kebijakan publik: Konsep dan aplikasi analisis proses kebijakan publik. Sidoarjo: Banyumedia Publishing.

Winarno, B. (2007). Kebijakan publik: Teori dan proses (2nd ed.). Yogyakarta: Media Presindo. 